\title{
КОРПОРАТИВИЗМ ИЛИ ПЛЮРАЛИЗМ? ИНСТИТУЦИОНАЛЬНЫЕ МОДЕЛИ ВЗАИМОДЕЙСТВИЯ СОВРЕМЕННОГО ГОСУДАРСТВА И ОБЩЕСТВА
}

\author{
Шапкин И. Н. *
}

В нынешних условиях все большее значение приобретает деятельность всевозможных групп интересов, численность которых постоянно возрастает. Их взаимодействие с государством носит многосторонний характер. Сегодня сложились две модели взаимодействия власти и общества, которые получили теоретическое оформление в виде корпоративной и плюралистической концепций. В данной статье анализируются причины, приведшие к появлению корпоративной и плюралистической моделей общественного развития, основные принципь указанных теоретических систем. Анализ подобной практики имеет актуальное научно-практическое значение в условиях совершенствующейся рыночной экономики и формирующегося гражданского обиества.

Ключевые слова: группь интересов, корпоративизм, плюрализм, институционализм, трипартизм, сочиальное партнерство, функциональное представительство, политическая конкуренция.

In the current situation, the activities of various interest groups, whose number is constantly increasing, become more and more important. Their interaction with state is multifaceted. Today we have two models of interaction between authorities and companies that have received theoretical arrangement in the corporate and pluralistic concepts. This article analyzes the causes that led to the emergence of corporate and pluralist models of social development, the basic principles of these theoretical systems. The analysis of these practices has important scientific and practical value in terms of improving the market economy and the emerging civil society.

Keywords: interest groups, corporatism, pluralism, institutionalism, tripartism, social partnership, functional representation, political competition.

В современном глобальном мире существует два механизма согласования позиций государства и общества. Один предполагает функционирование политических партий, другой - деятельность организованных групп интересов.

Осознание индивидами схожести интересов приводит к структурированию общегруппового интереса и, как следствие, к формированию в недрах социальной группы инициативного ядра, которое превращает аморфное образование в организованный коллектив, сплоченный общими интересами. Именно эта группа берет на себя разработку стратегии и тактики активного действия представляемого сообщества и выступает в качестве идеолога данного интереса и активного актора

* Шапкин Игорь Николаевич - д. э. н., профессор Финансового университета при Правительстве РФ. E-mail: ishapkin@fa.ru.

Век глобализации 1/2018 24-39 
в его отстаивании в органах власти. Каждая группа интересов отличается по целям и методам деятельности, ресурсам и возможности влияния на власть, а также присущим только ей набором характеристик. Цель групп интересов состоит в активном взаимодействии с властью для того, чтобы их интересы и запросы были не только услышаны, но и получили конкретное практическое воплощение. Государство выстраивает отношения с этими структурами для выработки адекватной и сбалансированной внешней и внутренней политики.

Взаимодействие групп интересов с государством осуществляется в рамках двух политических моделей, которые оформлены в виде двух концепций - плюрализма и (нео)корпоративизма.

В наибольшей степени эти модели реализованы в западноевропейских странах и США. Их истоки следует искать в особом историческом развитии Западной Европы. Под влиянием Гуманизма, Реформации, Возрождения и Просвещения здесь сформировалось уникальное сообщество, членов которого отличали новое мировоззрение, идеология и морально-этические ценности - индивидуализм, стремление к личному и земному благополучию, освобождение от христианских обязательств и подчинение действий и поступков индивида рационализму. Власть и стремление к власти, экономические цели и процессы стали наполняться рационализмом. Теперь индивиды руководствовались не честью и верностью, а рациональными интересами и предпочтениями.

Если прежде считалось, что действиями людей руководит добродетель, то после XVIII в. представления о добре и благополучии принципиально изменились. Они стали носить субъективный характер. Каждый человек становился арбитром «полезной добродетели», определенной «естественным порядком». Как разумное существо человек не может не стремиться к максимизации материалистической полезности.

«Экономический человек» ответственен за реализацию собственного потенциала посредством максимизации полезности. Свое политическое участие в делах государства он осуществляет через демократические институты. Такой подход поощрял эгоцентристские настроения в обществе, формировал личность, отличавшуюся эгоизмом, размытыми понятиями о совести, порядочности, новым поведением. Для нее были характерны напор и агрессия. Следствием этого стали межличностные, групповые и межгосударственные конфликты, сотрясавшие мир и Европу на протяжении последних трехсот лет. Нередко люди, исповедующие рационализм и стремящиеся к полезности, используют власть, чтобы получить несправедливое преимущество. Господство над другими и использование силы для того, чтобы заполучить желанные вещи на неравных условиях, как писал А. Шопенгауэр, - это наилучший способ максимизации полезности [Роузфилд 2004: 77-78]. Чтобы не допустить конфликтов в обществе и контролировать отклонения в поведении и поступках человека, необходимо, как писали деятели Просвещения и представители классической политической экономии, опираться на конкуренцию, совесть и верховенство права.

Наиболее последовательно идеалы нового общественного устройства были реализованы в США. Центральным элементом американской общественной системы являются: индивидуализм, общественный договор, обязательство соблюдать незыблемость договорного права, жажда наживы, трудолюбие, предпринимательство и свобода. Все это дополняется государством, выполняющим роль 
«ночного сторожа», то есть обеспечивающим соблюдение законности и порядка и собирающим на собственные нужды средства с общества посредством налогов. Предпочтение, отдаваемое в англо-американских культурных традициях верховенству свободы, предпринимательству и примату права, сильно отличает эту систему от традиций стран континентальной Европы, для которых характерны этатизм, коллективизм и корпоративизм [Роузфилд 2004: 127].

Новая культурно-идеологическая среда, сложившаяся на берегах Атлантического океана, оказывала определяющее влияние на индивидуальные и групповые, общественные и личные приоритеты европейцев, формировала новое ви́дение индивидом своего места в общественно-политической жизни. После Просвещения человек начал воспринимать себя как активный актор исторического процесса. Впервые он заявил государству о своих претензиях на эту роль. Бурная политическая жизнь Европы XVIII-XIX вв. свидетельствовала об обоснованности подобных притязаний. Возросшая социально-политическая активность масс вынуждала государство строить новые отношения с ними, создавать особые принципы и механизмы взаимоотношения с обществом.

Корпоративные взгляды в европейском обществе имеют давние и глубокие исторические традиции, восходящие к теоретическому наследию Г. В. Ф. Гегеля в вопросах отношения «человек - общество - государство», социальной доктрине католицизма, правым социалистическим течениям I и II Интернационалов [Шапкин 2016].

Под корпоративизмом понимается такая организация общественной жизни, при которой отношения между группами интересов и государством реализуются через объединения физических и юридических лиц, то есть корпорации.

Термин «корпорация» возник в Западной Европе в период Средневековья. B XI-XV вв. корпорациями назывались сословия, а также профессиональные организации цехового типа, защищавшие интересы своих членов. Вхождение индивида в ту или иную корпорацию определяло возможности его профессиональной деятельности и отстаивания социальных интересов. Вне корпорации жизнь человека была невозможна. Организации являлись своего рода переходным звеном между общинным типом представительства и гражданским обществом. «Ренессанс» корпоративных организаций пришелся на период индустриального развития. Для маргинализированных масс корпорация стала едва ли не единственной социально приемлемой формой организации. В середине прошлого века корпоративизм трансформировался в неокорпоративизм, который связан с именами А. Коусона, Дж. Лембруха, Ф. Шмиттера, Г. Штрека и др.

Согласно этой концепции, индивиды могут влиять на решения, принимаемые государством, посредством членства в корпоративных органах - профсоюзах, профессиональных организациях, группах политического давления и лобби, добровольных объединениях. Являясь составной частью гражданского общества, эти структуры добиваются своих целей не в рамках публичной политики, как политические партии, а путем прямого воздействия на государственные институты. Корпорации, используя разнообразные приемы и методы, добиваются принятия государственными учреждениями и ведомствами необходимых решений.

Однако государство входит в отношения не со всеми корпорациями, а лишь с наиболее значимыми, занимающими особое положение в обществе. Именно они и получают более широкие возможности для оказания влияния на принятие ре- 
шений. В таких условиях политическая конкуренция организованных групп интересов заменяется монополией отдельных привилегированных объединений [Шмиттер 1997: 17].

Особое внимание теоретики корпоративизма уделяют координации взаимоотношений власти и общественных организаций, поскольку на основе согласования государственной политики и общественных интересов и принимаются политические решения, которые призваны обеспечить общественный прогресс, достижение консенсуса и согласия в обществе. В корпоративной государственнополитической системе важнейшими аспектами публичной политики являются консультации правительства с организованными группами интересов, например с профсоюзами и бизнес-ассоциациями.

В обмен на доступ к принятию решений группы интересов обеспечивают лояльность государству, содействуя тем самым проведению согласованной экономической и социальной политики. Важнейшим условием развития корпоративных отношений является наличие сильных централизованных организаций, обладающих способностью сплотить группы, даже используя репрессивные санкции к тем членам, которые нарушили условия соглашения с властью.

В формировании корпораций значительную роль играет государство. В ответ на государственную помощь и поддержку европейский бизнес, например, соглашается на ограничение продолжительности рабочего дня и увольнений, предоставление гарантий защиты от увольнений, достаточно длительный отпуск и высокие пенсии, ограничивает полномочия администрации, допуская работников к управлению предприятием. Он соглашается на дополнительные затраты на рабочую силу, устанавливая минимальную заработную плату; на обязательный выход на пенсию по достижению определенного возраста, неся немалые расходы по медицинскому и другим видам социального страхования; берет на себя финансирование дополнительных выплат (помимо прямой зарплаты); обеспечивает установленные условия занятости и обязательную оплату сверхурочных. В свою очередь, наемные работники обязуются квалифицированно и качественно трудиться на своих работодателей, государство и общество [Роузфилд 2004: 167].

От государства и деятельности его институтов зависят сила и способность корпораций реализовать свои групповые интересы. Значимость и влиятельность корпораций зависят от следующего:

- во-первых, от ресурсов, в том числе и от того, какие средства выделит им государство в виде дотаций, налоговых льгот, «монопольных» связей с государственными органами, средствами массовой информации и т. д.;

- во-вторых, от представительного характера организации, то есть насколько широко и полно она отражает интересы социально значимых групп общества, от легитимных рамок и механизмов функционирования данной группы интересов;

- в-третьих, от организационной структуры, то есть от того, каковы внутренняя конструкция, масштаб членства, степень сплоченности корпорации, внутренний порядок и механизмы ее функционирования;

- в-четвертых, от правового статуса, то есть от того, какое место группа интересов занимает в правовой системе, в подготовке законов и реализации политики, каково их отношение с остальными действующими лицами политического процесса [Аг 1995: 63]. 
«Нет больше “улицы с односторонним движением”: от общества через объединения и партии к исполнительной власти, - писали У. фон Алеман и Р. Г. Хайнц в 1981 г., то есть в период повышенного интереса к вопросам корпоративизма. - Существует скорее сеть отношений: функциональное переплетение между государственными и негосударственными институтами накладывается на классическое разделение власти и типичное для федерализма вертикальное политическое переплетение между федерацией, землями и коммунами. Это ведет и к преобразованию объединений... В рамках такой перемены отношений между государством и экономикой крупные объединения принимают функции шарниров и буферов... Общее для всех уровней - форсированное включение негосударственных организаций в официальную политику. Наряду с традиционными органами формирования консенсуса, прежде всего парламентом, возникают новые, параконституционные системы переговоров, указывающие на возрастающее обобществление процессов принятия политических решений» [Crouch 1983: $128-129]$.

Современный корпоративизм - довольно аморфная система взглядов, поэтому его «определяли и как идеологию, и как тип политической культуры или государственного устройства, и как форму организации экономики, и даже как тип общественной организации; наиболее продуктивным все же представляется подход, в рамках которого он рассматривается как один из возможных политических институтов, чье назначение заключается в том, чтобы дать возможность организованным группам интересов стать реальными посредниками между своими членами (индивидами, семьями, фирмами, локальными сообществами и т. д.) и различными политическими субъектами (в особенности государственными и правительственными органами)...» [Шмиттер].

В нынешнем корпоративизме можно выделить несколько направлений.

1. Неокорпоративизм как форма государственного устройства, в которой корпоративизм развивается параллельно парламентской системе. При парламентском строе процессы представительства и вмешательства разделены. В корпоративном государстве они слиты. Корпорации представляют интересы своих членов и действуют как посредники при проведении в жизнь правительственной политики. Корпорации находятся в постоянном диалоге с государственными чиновниками, итогом этих контактов являются согласованные решения, обязательные для выполнения всеми сторонами процесса.

2. Неокорпоративизм как способ организации интересов и взаимодействия с государством, способ, отличный от прежних. Основное положение представителей этого направления основано на различии корпоративизма и плюрализма.

3. Неокорпоративизм, понимаемый как новая система политической экономии, которая отличается от капитализма и социализма и представляет особый, «третий путь» общественного развития. Это направление является продолжением представлений корпоративистов 1920-1930-х гг.

Для них характерны независимость государства от частного сектора и замена рыночных механизмов практикой олигополии. Экономическая система этого варианта корпоративизма основана на отказе от свободы деятельности частного капитала и переходе к государственному управлению, основанному на четырех принципах: единстве, порядке, национализме, успехе. 
Теория корпоративизма и корпоративистские взгляды оказывали и оказывают большое влияние на развитие всех социальных наук, в частности экономических. «Неокорпоративистский подход, - писал Ф. Шмиттер, - это лишь один из подвидов более широкого класса теоретических подходов в политической экономии, известных под названием “институционализм". Общим для всех институционалистских теорий является представление о том, что поведение людей - будь то экономическое, социальное или политическое - невозможно объяснить, исходя исключительно из выбора и предпочтений индивидов либо из коллективной идентичности и обязательств, налагаемых группой.

Данный тезис направлен против ставшего в последнее время довольно модным предположения, что все действия людей могут быть сведены - методологически или эмпирически - к рациональному расчету конкурирующих особей. Одновременно он противостоит идее, которая была весьма популярна в прошлом, что все происходящее вытекает из особенностей глобальных сущностей - племен, общин, классов, наций, “систем” и т. п.» [Шмиттер 1997].

Использование корпоративистского подхода позволило исследовать: политические, социальные и юридические нормы, регулирующие общественные отношения, в рамках которых протекают процессы производства и обмена (Дж. Бьюкенен, Г. Таллок); группы интересов, поведение и роль государства в хозяйственной жизни общества, экономические механизмы власти, процесс принятия правительственных решений (М. Олсон); роль и значение стандартизации и формализации прав собственности, с помощью неоинституционального подхода провести анализ рыночных реформ (Э. де Сото) [Бьюкенен, Таллок 1997; Олсон; Сото 2007].

«"Мода" на корпоративизм, без сомнения, - как справедливо отмечал Ф. Шмиттер, - имеет свои приливы и отливы, причем весьма регулярные. После Первой мировой войны понятие “корпоративизм” всплыло вновь, причем на этот раз в более светском и этатистском обличье, и нашло свое самое наглядное выражение в corporazioni фашистской Италии, за которой последовали Португалия, Испания, Бразилия, вишистская Франция и ряд других стран» [Шмиттер 1997].

В 1920-1930-е гг. корпоративизм стал своеобразным идеологическим прикрытием политики всеобъемлющего контроля правительства и правящей партии над обществом. Концепция корпоративизма была использована фашистскими и некоторыми правыми государствами для создания новой корпоративной экономики. Фашистские теоретики определяли корпоративизм как «новый тип политической цивилизации», как третий вариант общественного развития, противостоящий западному либерализму с его свободным рынком и прямой либеральной демократией, которая после мирового кризиса 1929-1933 гг. полностью дискредитировала себя, и государственному социализму СССР с полным огосударствлением экономической и социальной жизни [Белоусов 2012; Шапкин 2017].

Практическую реализацию корпоративистский идеал получил в фашистской Италии. Здесь на региональном уровне создавались профессиональные синдикаты, объединявшие работников и работодателей. Местные синдикаты составляли национальные федерации, которые, в свою очередь, входили в конфедерации работников и работодателей, охватывавшие широкие сектора хозяйства: промышленность, сельское хозяйство, торговлю и т. д. В 1934 г. власти заявили о создании в стране 22 подобных объединений. Эти корпорации получили полномочия в решении некоторых хозяйственных вопросов, например, ценового регулирова- 
ния, посредничества в трудовых спорах. Однако итальянскому «корпоративному государству» не удалось добиться компромисса между группами экономических интересов, а созданные корпорации представляли секторные экономические структуры, организованные и руководимые властью для укрепления диктаторского режима. Ни предприниматели, ни трудящиеся не обладали самостоятельными правами [Хиггс].

После Второй мировой войны корпоративизм, который незаслуженно связали с фашистским и другими правыми режимами, исчез как направление общественной мысли на два с лишним десятилетия. Корпоративизм стал синонимом недемократичности.

Но едва послевоенная волна демократизации, по замечанию Ф. Шмиттера, смыла с лица Европы корпоративные структуры авторитарно-этатистского или фашистского толка, корпоративизм вновь заявил о себе, но уже в неокорпоративной форме. В наибольшей мере неокорпоративизм проявился в малых европейских странах с относительным культурным и языковым единством, в странах с хорошо организованными ассоциациями интересов, и в первую очередь там, где имелись мощные социал-демократические партии - в Бельгии, Дании, Нидерландах, Швеции, Норвегии, Финляндии [Шмиттер 1997: 17].

В немалой степени формированию неокорпоративизма способствовали традиции, опыт корпоративного строительства предшествующих эпох; субъекты корпоративизма, то есть различные общественные организации, в том числе предпринимательские союзы и профсоюзы, имевшие позитивный опыт взаимодействия с властью, а также государство, приступившее к активному реформированию существовавшего общественно-политического устройства. В послевоенный период экономическая роль государства возросла, поэтому неокорпоративисты обращали внимание на необходимость в связи с этим сотрудничества с государственными институтами. Для них корпоративизм - «это экономическая система, предполагающая, подобно социализму, высокий уровень активности государства, в которой, однако, государство играет качественно иную роль» [Бьюкенен, Таллок 1997: 12].

Важнейшим условием распространения и развития неокорпоративистских взглядов явились глубокие изменения в социально-экономической жизни Западной Европы в середине XX в. Здесь постепенно сложились новые реалии: включение групп интересов в процесс принятия решений государством; создание социальных пактов, гарантировавших мирное развитие трудовых отношений и превращение профсоюзов, предпринимателей и правительственных институтов в социальных партнеров; формирование новой промышленной политики, предполагавшей обязательные консультации по важнейшим вопросам с представителями бизнеса и профсоюзов; проведение новой политики в области социальной защиты и образования; привлечение групп интересов к процессам экономического и социального реформирования. Начался процесс распада традиционных социальных страт (рабочий класс, мелкая буржуазия, крестьянство и т. д.) и образования новых. Менялись образ жизни населения, экономическое и политическое поведение людей, возросла социальная и географическая мобильность и т. д.

«Именно во второй половине XX в., - писал английский исследователь К. Кроуч, - возникла, по крайней мере временно, более надежная основа национального согласия между организованным трудом и организованным капиталом, 
чем католическая теология. Речь идет о государстве всеобщего благосостояния, кейнсианской экономике и участии рабочих партий в управлении смешанной экономикой. Это совсем не те элементы, о которых говорили в 1870-х гг., однако у “классического" корпоративизма XIX в. и современного неокорпоративизма гораздо больше общего между собой, чем у них обоих - с фашистским извращением корпоративизма. Теоретики прошлого могли заблуждаться насчет содержания согласия, но они не так уж ошиблись в том, что касается его формы. Более того, если вспомнить, что Дюркгейм и его последователи часто называли себя социалистами (не говоря, разумеется, о “гильдейских социалистах"), расстояние между классическим корпоративизмом и скандинавским опытом покажется не таким большим. А в таких “демократиях сообществ”, как Австрия и Нидерланды, социалистические и католические версии корпоративизма любопытным образом уживаются друг с другом» [Almond, Verba 1965: 460].

Неокорпоративизм нередко отождествляют с социальным партнерством, в том числе с трипартизмом, то есть сотрудничеством государства, профсоюзов и предпринимательских организаций для решения распределительных и трудовых отношений; но существует и иная точка зрения, согласно которой неокорпоративизм и социальное партнерство - совершенно разнородные категории [Салмин 1984: 1].

По нашему мнению, такое противопоставление неверно, поскольку социальное партнерство - это одно из проявлений корпоративизма, практическая реализация корпоративистских представлений. Корпоративизм шире социального партнерства. Он подразумевает более широкое представительство участников диалога государства и общества.

Социальное партнерство - это форма организации политической жизни, рассчитанная на долгосрочное функционирование и ориентированная как на регулирование взаимоотношений между трудом и капиталом, так и на решение конкретных острых проблем (инфляция, безработица, вопросы социального обеспечения).

Экономический эффект социального партнерства состоит в стабилизации уровня занятости и распределения доходов, а также в положительном влиянии на экономический рост и на стабильность в сфере денежного обращения. Социальное партнерство влияет на социальную стабильность, ограничивая рост конфликтов [Там же: 22-24].

Экономическая система стран континентальной Европы представляет собой рыночную экономику, в которой сочетаются индивидуализм и корпоративизм. Рыночная система регулируется в соответствии с ее культурными традициями, сочетающими в себе элементы индивидуализма, корпоративистские и государственные стратегии социальной защиты. Эта система возникла в конце XIX в. и в последующий период развивалась, пытаясь примирить индивидуализм (как его корыстно-эгоистический, так и гуманистический аспекты) с государственной социальной защитой, профессиональными союзами, регулированием экономики, государственной и коммунальной собственностью.

Индивидуализм делает европейцев независимыми, зачастую весьма агрессивными в отстаивании своих корыстных интересов, материалистами, иногда склонными к анархизму, выступающими против государства, авторитаризма и даже частной собственности. Коллективизм делает их зависимыми, стремящими- 
ся к уверенности в завтрашнем дне, готовыми подчиниться власти группы, к которой они принадлежат, и выполнять обязательства перед ней.

Эти противоречивые тенденции на протяжении веков гармонизировались под воздействием эволюционизирующегося корпоративизма - изменения институтов и отношений, позволяющих гражданам иметь частную собственность, стремиться к полезности и прибыли на рынке и при этом подчиняться коллективу и выполнять определенные обязательства перед ним.

Наибольшее развитие корпоративизм получил в экономической и социальной сферах. В Германии он оформился в виде «согласованного действия концернов», в Великобритании - «социального контракта», в Бельгии - «социального программирования» и т. д. [Ильичева 2002: 79]. В Австрии создана система экономического и социального партнерства, успешно функционирующая в течение десятилетий. Институциональной базой для нее служит паритетный комитет, в котором предприниматели представлены председателями Федеральной экономической палаты и сельскохозяйственных палат; наемные работники - членами палат рабочих, служащих, работников транспорта и профсоюзами.

Председателем паритетного комитета является федеральный канцлер, одним из членов комитета (без права голоса) - министр, ответственный за экономические вопросы. Комитет имеет две постоянные подкомиссии - по заработной плате и ценам. Но в действительности он работает как экономический и социальный совет, выдвигая на повестку дня комплексные вопросы экономического и социально-политического характера. Основной принцип деятельности комитета - это достижение единогласия между договаривающимися сторонами. Принятие решений носит неформальный и непубличный характер.

Важнейшие социально-экономические законы обсуждаются и готовятся непосредственно организациями-партнерами - Федеральной экономической палатой и профсоюзами. Затем эти законы, в сущности, лишь ратифицируются правительством и парламентом. Это относится, например, к принятию закона о праве на труд, который значительно расширил участие лиц наемного труда в делах производства, правовому регулированию занятости иностранных рабочих, закону о конкуренции и т. д. [Роман 1995: 110]. Заметим, что существование партнерства никак не отражено в австрийском законодательстве.

Австрийская система имеет длительную историю. Еще в конце XIX в. австрийское государство приступило к модернизации экономики, которая потребовала, с одной стороны, учета интересов предпринимателей и наемных работников, а с другой - того, что профсоюзы не пользовались авторитетом среди наемных работников в отличие от социал-демократической партии и социальнохристианского движения. С конца 1870-х гг. одним из требований рабочих являлось создание рабочих палат. В 1920 г. такая система палат была создана, произошли укрупнение и централизация профсоюзов, началось сотрудничество государства с организованными группами интересов, оформились идеологические элементы сотрудничества: реформизм, ориентация на государство, идеология согласия, стремление к гармоничному сочетанию интересов различных общественных сил.

В условиях мирового экономического кризиса 1929-1933 гг. отношения между сторонниками социал-демократии и правительством обострялись, подрывались основы социального сотрудничества. Профсоюзы ограничились деятельностью на 
уровне предприятий и борьбой за заработную плату, а в правящей среде усиливались антипарламентские настроения. Таким образом, к началу 1930-х гг. в Австрии был заложен институциональный фундамент социального партнерства.

В условиях австрофашизма все корпоративистские институты оказались под контролем государства. Корпоративизм стал формой принудительного сотрудничества при ликвидации правового государства. Но именно тогда были созданы институты, ставшие впоследствии базой послевоенного социального партнерства и институциональной основой согласования интересов при решении макроэкономических и общегосударственных проблем - единый профсоюз, Федеральная промышленная палата. В послевоенной Австрии определяющим основанием для формирования системы социального партнерства явилась национализация экономики, а также изменения в выработке подходов к принятию решений, в частности отказе профсоюзов от конфронтации с бизнесом и властью, переходу к диалогу с ней. Здесь постепенно сформировалась трипартистская форма согласования интересов, субъектами которой стали профсоюзы, предприниматели и правительство.

Органы, регулирующие рынок рабочей силы и осуществляющие комплекс мер по ограничению масштабов и смягчению последствий безработицы, были созданы также в Швеции, Великобритании, Нидерландах. В 1950-1970-х гг. широкое распространение получили трипартистские структуры. Их роль не ограничивалась достижением консенсуса между основными социальными партнерами. В некоторых странах (Швеция, Австралия и др.) они превратились в органы, определяющие направление социально-экономической стратегии государства.

В хозяйственной сфере тесное взаимодействие трех основных акторов политического процесса - государства, союзов предпринимателей и профсоюзов - повысило эффективность управления, способствовало экономическому росту, обеспечило политическую стабильность. К несомненным достоинствам корпоративной модели можно отнести повышение эффективности финансовой системы, большую сбалансированность бюджета, снижение уровня инфляции, сокращение безработицы, угасание классовой борьбы.

Созданная система является более эффективной, поскольку в ее рамках сила коллективизма используется для повышения трудолюбия, ради смягчения напряженности во взаимоотношениях между наемными работниками и владельцами предприятий. Эта система способствует выработке групповых знаний, повышению качества, координированию и планированию, созданию атмосферы доверия. Она учитывает интересы всех заинтересованных лиц, участвует в распределении риска, регулирует конкретный и совокупный спрос, создает атмосферу гражданской и социальной ответственности.

Вместе с тем замедление экономического роста, развитие иждивенческих настроений в обществе заставили руководителей ряда государств (Германия, Франция, Швеция) для разрешения возникших проблем перенять некоторые элементы англо-американской модели. Был ограничен рост государственных расходов; сокращены предельные ставки налогообложения; поощрялась либерализация норм, регулировавших использование рабочей силы; сократились выплаты, не обеспеченные финансированием; проводилась денационализация большинства отраслей промышленности; активно привлекались иностранные инвестиции; ока- 
зывалась поддержка процессу интеграции Европы, которая включала создание валютного союза.

Результатом взаимных стремлений государства и групп интересов к совместной деятельности стало создание особой системы, для которой характерно наличие прямых связей между группами интересов и органами государственной власти. Такая система получила название «функциональное представительство». В течение последних десятилетий оно является органической частью государственного управления.

Во многих странах сложились национальные системы такого представительства. Но у всех у них есть общие черты: наличие специальных институтов и учреждений, в рамках которых осуществляется диалог представителей организованных интересов и государства; принципы организации и способы деятельности таких институтов, существование системы неформальных связей и отношений, нередко играющих роль более важную, чем формализованные связи. Пример формализованных структур - это советы, различные комитеты при органах исполнительной власти, которые состоят из руководителей данных органов, представителей групп интересов и независимых экспертов. Большинство таких комитетов существует на постоянной основе, часть же создается для поиска решений по конкретным проблемам.

В последние десятилетия сторонники индивидуализма, либерализации и глобализации по-американски подвергают критике систему корпоративизма. Из-за него, по их мнению, экономика объединенной Европы работает не в полную мощь. Она лишена гибкости и открытости к нововведениям, а принимаемые решения непрозрачны. В условиях экономического динамизма она консервативна, не стимулирует менеджмент и рабочую силу к повышению качества работы.

Корпоративизм создает иждивенческие настроения, стремление «проехаться за чужой счет», формирует антитрудовую этику. Эта система налагает групповые обязательства, которые население не принимает и которые приводят к ухудшению качества жизни. Люди видят в корпоративизме, неэффективной системе государственного протекционизма причину замедления темпов экономического роста, сохранения высокого уровня безработицы, неполной занятости [Роузфилд 2004: 176-177].

Противники отмечают падение эффективности институтов, обеспечивавших достижения корпоративизма, в частности трипартизма. Причина состоит в кризисе профсоюзов, ослаблении их влияния среди наемных работников, а также в укреплении позиций бизнеса, который предпочитает решать проблемы напрямую с правительствами. Он часто не соглашается на участие профсоюзов в переговорах и консультациях.

Противники этой системы призывают отказаться от всех антиконкурентных корпоративистских ограничений. Несмотря на критику, система функционального представительства продолжает развиваться в целом ряде стран.

Второй моделью взаимоотношения государства и общества является плюрализм. В наиболее полном виде она представлена в США. С самого начала здесь политическая роль общественных и экономических сил, оформленных в различные организации, была выражена сильнее, чем в Западной Европе. Для американской политической науки именно совокупность множества этих действующих 
лиц, находящихся в постоянном взаимодействии, и составляет сущность политической системы.

«Слабое», нецентрализованное государство в этой системе ведет очень широкую деятельность, влияет почти на все сферы общественной жизни, но достигается это не «европейскими» методами, то есть не концентрацией государственной власти, а расширением функций «услуг». Ответом на кажущееся противоречие между «сильным» государством и его широкой деятельностью служит государственная политика, которая является не чем иным, как в соответствии с сущностью «государства услуг» регулируемой совместной деятельностью всех общественных действующих лиц в принятии и реализации решений [Аг 1995: 60].

Поэтому именно в США сформировалась теория плюрализма, основные идеи которого были сформулированы Р. Далем, Е. Латамом и др. Плюрализм превратил группы в основных агентов, связывающих государство и общество, в главных субъектов государственного управления. Группы интересов смогут лучше донести свои нужды и требования до правительства через проявление социальной активности.

Группы интересов, объединенные в общественные организации, являются основными агентами, связывающими государство и общество, поскольку в сложноорганизованном обществе человек имеет мало шансов быть услышанным властью и еще меньше повлиять на правительственные решения. На основе эмпирических исследований Р. Даль пришел к выводу, что организации групп интересов «необходимы для функционирования демократического процесса как такового, для минимизации правительственного принуждения, для политической свободы и для человеческого благополучия» [Dahl 1982: 1].

В таких условиях коллективная (групповая) точка зрения обладает бо́льшим значением для власти, чем индивидуальный голос, а сформированные группы представляют собой каналы, через которые люди реализуют свои демократические права и вступают во взаимодействие с правительством.

В соответствии с главным принципом плюрализма политическая система состоит из конкурирующих друг с другом организованных групп интересов и строится на их постоянной конфронтации. Критерием демократизма или либерализма является наличие большого числа групп интересов, между которыми возможна свободная конкуренция.

Правительству плюралисты отводят роль посредника во взаимодействии между заинтересованными группами. Каждая группа действует в собственных интересах. Исполнительная власть должна добиваться координации действий всех участников политического процесса, стремиться к достижению компромиссов. Государство выступает как незаинтересованный арбитр, позитивно реагирующий на воздействие множества групповых притязаний и фиксирующий в своих решениях достигнутый баланс интересов. Эти решения отражают разнообразие мнений и общественных потребностей, становятся результатом компромиссов противостоящих групп. Как отметил Е. Латам, «каждый нормативный документ представляет собой некий компромисс, поскольку разрешение межгрупповых конфликтов - это процесс обсуждения и поиска согласия» [Latham 1952: 390].

Р. Даль полагал, что соперничество групп в какой-то степени аналогично конкуренции в экономике, позволяющей установить равновесие между спросом и предложением. «Плюрализм - это политический аналог экономики свободного 
рынка» [Золотарева 1999: 63-75]. Столкновение конкурирующих групп обеспечивает динамизм и равновесие общественно-политической системы. Принятие государственного решения, таким образом, - это результат свободной политической конкуренции между заинтересованными группами интересов, победы одних групп над другими, конкуренции, позволяющей установить равновесие между спросом и предложением [Almond, Verba 1965: 245].

Государство является своеобразным политическим рынком, который «фильтрует требования и интересы соперничающих групп и индивидов», а «правила рыночной торговли: учет спроса и предложения, стремление к выгоде, выравнивание цен и конкуренция продавцов и покупателей... выступают регуляторами, автоматически (без внешнего принуждения) обеспечивающими функционирование политической системы общества» [Павроз 2009: 8-9].

Если политическое влияние отдельных групп возрастает несоразмерно их реальной общественной значимости, а политика, которую проводит правительство под давлением этих групп, не соответствует воле большинства, то благодаря механизму конкуренции увеличивается численность оппозиционно настроенных групп, ставящих правительство перед выбором: либо изменить или внести корректировку в официальный курс, либо утратить общественную поддержку.

Степень влияния соперничающих групп на политический процесс обусловлена располагаемыми ресурсами. Однако политическая инициатива и реальное политическое влияние осуществляются не самой группой, а ее лидерами. Препятствием на пути узурпации власти какой-либо группой являются, по мнению Р. Даля, признание гражданами и элитами демократических ценностей и норм, следование «правилам игры», закрепленным в конституции и других правовых актах.

Общественно-политическое развитие конца 1960-х гг. показало, что реальность гораздо сложнее теоретических построений. Практика поставила под сомнение широко распространенное мнение плюралистов о том, что соревнование групп интересов обеспечивает всем равный доступ к ресурсам власти.

Теория плюрализма была подвергнута критике. Ее оппоненты говорили о «чрезмерной власти союзов», о «государстве союзов и профсоюзов», о том, что возникает опасность неуправляемости и хаоса. По этой, в частности, причине ее оппоненты требуют принятия закона о союзах для того, чтобы ограничить их стремление направить государство в нужном им направлении. Они доказывали, что в плюралистическом обществе «слабые интересы» не играют роли, их трудно организовать и у них мало шансов на реализацию, что новые интересы с трудом могут быть включены в сильные группы интересов [Аг 1995: 28, 30].

Критики плюралистического общества обвинили Р. Даля в недемократичности, утверждая, что чрезмерно развитые внегосударственные организации порождают такие связи между правящими и управляемыми, которые недемократичны сами по себе, поскольку не регулируются демократическими инструментами и механизмами, ведь группы интересов - это формально неполитические организации.

Другой аргумент критиков состоял в том, что «волюнтаристские ассоциации и организации, которые, по мнению теоретиков плюрализма, существуют для поддержки индивида перед унифицированной мощью правительства, сами по себе стали “олигархически управляемыми иерархическими структурами”» [Myсихин]. 
А. Блайндер ** справедливо заметил, что «плюрализм процветает на изобилии и, по-видимому, в благополучные времена, когда добродетели плюралистического государства - терпимость многообразия, компромисс, прагматизм - перевешивают один смертельный порок правления методом фракционной политики, а именно его неспособность преследовать общий общественный интерес» [Зяблюк 1999].

1. Существующие в современном мире корпоративные модели определяются наследием прошлого и политическими реалиями настоящего. Нынешний корпоративизм является инструментом примирения различных общественных интересов посредством переговорных процессов. Он включен в систему государственного управления. Его отличает отсутствие каких-либо связей и интереса к католическому корпоративизму. Неокорпоративистов не интересуют идеи социального христианства, но они не связаны и с идеологией фашистского корпоративизма.

2. Неокорпоративная модель обладает важными достоинствами. Она оказывает влияние на социальную стабильность, ограничивая рост конфликтов, повышает эффективность управления, сохраняет политическую стабильность общества и т. д. Экономический эффект неокорпоративизма состоит в стабилизации уровня занятости, распределения доходов, а также в положительном влиянии на экономический рост.

Благодаря неокорпоративистской политике стало возможным проведение сбалансированной социально-экономической политики. Она позволила включить группы интересов в процесс принятия политических решений; создать социальные пакты, гарантировавшие мирные трудовые отношения и превращавшие вчерашних антагонистов - профсоюзы, бизнес и государственные институты - в социальных партнеров; проводить экономическую политику, предполагавшую консультации властных органов по ключевым вопросам с представителями бизнеса и профсоюзов; осуществлять социально-экономическую политику, подразумевавшую учет интересов разных социальных групп в разных сферах.

3. Наряду с достоинствами современная неокорпоративная модель имеет и издержки, связанные в первую очередь с недостаточной гибкостью и открытостью в отношении нововведений, а также непрозрачностью принятия решений.

4. Плюрализм не получил широкого распространения в Европе. Он характерен для англосаксонских стран. США являются неким «эталоном», реализовавшим в полной мере плюралистические представления. Не задавая строгих правил при согласовании интересов, плюрализм ориентируется на развитие конкурентных начал в политике. Как любое общественное явление, плюрализм обладает достоинствами и недостатками. К несомненным его достоинствам относятся оперативность, гибкость принятия политических решений, а к недостаткам - то, что доступ к власти получают преимущественно самые влиятельные ассоциации, которые оттесняют другие группы интересов на второй план, что не всегда идет на пользу «общему делу».

\footnotetext{
** Член Совета экономических консультантов в первой администрации президента США Б. Клинтона, вице-председатель Совета управляющих Федеральной резервной системы (ФРС), а впоследствии профессор экономики Принстонского университета.
} 


\section{Лuтература}

Аг А. Организованные группы интересов и формирование государственной политики // Государственная служба. Группы интересов. Лоббирование. (Взгляд из-за рубежа.) Вып. 4 / отв. ред. Г. И. Иванов. М., 1995.

Белоусов Л. С. Корпоративизм и правовое регулирование трудовых конфликтов в Италии 1920-1930-х гг. // От античности до современности: сб. ст. М., 2012.

Бьюкенен Дж., Таллок Г. Расчет согласия. Логические основания конституционной демократии / Дж. Бьюкенен // Сочинения. Конституция экономической политики. Расчет согласия. Границы свободы. Т. 1. М., 1997.

Виноградова Т. И. Лоббирование как социальная технология // На пути к публичной политике: 10 лет стратегии. СПб., 2003.

Золотарева Е. В. Группы интересов в политике // Вестник Российского университета дружбы народов. Серия «Политология». 1999. № 1. С. 63-75.

Зяблюк Н. Г. Политический плюрализм: контуры американской модели // США и Канада: экономика, политика, культура. 1999. № 5. С. 9.

Ильичева Л. Е. Институционализация лоббизма в политическом процессе современной России (Становление, приоритеты, развитие): дис. ... д-ра полит. наук. М., 2002.

Мусихин Г. И. Плюрализм и корпоративизм как институциональные модели взаимодействия государства и общества [Электронный ресурс]. URL: http:/new.hse.ru/ sites/mbd/programs_doc/new_docs14.

Олсон М. Деволюция северной и немецкой экономик [Электронный ресурс]. URL: http://ie.boom.ru/Referat.

Павроз А. В. Теория политического плюрализма: сущность, противоречия, альтернативы. СПб., 2009.

Роман 3. Группы интересов и экономические палаты // Государственная служба. Группы интересов. Лоббирование. (Взгляд из-за рубежа.) Вып. 4 / отв. ред. Г. И. Иванов. М., 1995.

Роузфилд С. Сравнительная экономика стран мира. Культура, богатство и власть в XXI в. М., 2004.

Салмин А. М. Неокорпоративизм в странах Запада. Научно-аналитический обзор. M., 1984.

Сото Э. Иной путь: Экономический ответ терроризму. Челябинск, 2007.

Хиггс Р. Кризисы и квазикорпоративная политика в истории США [Электронный pecypc]. URL: http://www.cato.ru/pages/69?idcat=675\&parent_id=2.

Шапкин И. Н. Теоретико-методологические истоки теории корпоративизма // Гуманитарные науки. Вестник Финансового университета. 2016. № 3. С. 43-53.

Шапкин И. Н. Корпоративистская практика. Опыт создания «корпоративной» экономики в Италии, Австрии, Испании, Португалии в 1920-1930-х гг. // Гуманитарные науки. Вестник Финансового университета. 2017. № 3. С. 40-51.

Шмиттер Ф. Неокорпоративизм // Полис. 1997. № 2. С. 14-22. 
Шмиттер Ф. Неокорпоративизм и консолидация неодемократии [Электронный pecypc]. URL: http://www.zhurnal.ru/polit/articles/cup2.html.

Almond G., Verba S. The Civil Culture: Political Attitudes and Democracy in Five Nations. Boston, 1965.

Crouch C. Pluralism and the New Corporatism: A Rejoinder // Politic Studies. 1983. Vol. 31. No. 3.

Dahl R. A. Dilemmas of Pluralist Democracy. New Haven, 1982.

Latham E. The Group Basis of Politics: Notes for a Theory // American Political Science Review. 1952. Vol. 46. Pp. 376-397. 